\title{
Nanduty
}

ISSN:2317-8590

\section{QUEM É O PAI E QUEM É A MÃE? UMA REFLEX̃̃O SOBRE REPRODUÇÃO, PARENTESCO E HETEROCISCENTRISMO}

\author{
Anna Carolina Horstmann Amorim (UEMS - anna.amorim@uems.br) \\ Claudia Regina Nichnig (UNESPAR- claudianichnig@gmail.com) \\ Keo Silva (UFSC- keo.ech@ gmail.com)
}

\section{RESUMO}

TEMATIZANDO OS TENSIONAMENTOS SOBRE AS COMPREENSÕES DE FAMÍLIA, PRINCIPALMENTE QUANDO ESSAS ESCAPAM DAS NORMAS HETEROSSEXUAL E CISGÊNERA, DISCUTIREMOS, NESTE ARTIGO, DIFERENTES EXPERIÊNCIAS DE SER E FAZER FAMÍLIA NO BRASIL. APRESENTAREMOS A RELEVÂNCIA DOS DEBATES SOBRE PARENTESCO, GÊNERO E SEXUALIDADE EM INTERCONEXÃO COM O DIREITO, O ESTADO E A MEDICINA. AS TRANSIDENTIDADES, AS NORMATIZAÇÕES PROPOSTAS PELO CONSELHO FEDERAL DE MEDICINA, E O ACESSO AS TÉCNICAS DE REPRODUÇÃO ASSISTIDA, BEM COMO AS EXPERIÊNCIAS/DIFICULDADES DE UM CASAL TRANS PARA O REGISTRO DE SEU FILHO SERVEM DE SUBSÍDIO PARA O DEBATE QUE IREMOS REALIZAR.

PALAVRAS-CHAVE: PARENTESCO; IDENTIDADE DE GÊNERO, FAMÍLIAS.

\section{WHO IS THE FATHER AND WHO IS THE MOTHER? A REFLECTION ABOUT REPRODUCTION, KINSHIP AND HETEROCISCENTRISM}

\begin{abstract}
ABTRACT
DEPARTING FROM THE DISCUSSION ABOUT THE VARIED UNDESTANDINGS ABOUT FAMILIES, ESPECIALLY THOSE ESCAPING FROM THE HETEROSEXUAL AND CISGENDER NORMS, IN THIS ARTICLE WE DISCUSS DIFFERENT EXPERIENCES OF BEING PART AND THE MAKING OF A FAMÍLY IN BRAZIL. TO DO SO, WE PRESENT THE RELEVANCE OF DEBATES RELATED TO KINSHIP, GENDER AND SEXUALITY INTO THE LAW, STATE AND MEDICINE FIELDS. TRANSIDENTITIES, NORMATIVE RESOLUTIONS PROPOSED BY THE FEDERAL MEDICINE COUNCIL, ACCESS TO REPRODUCTIVE TECHNOLOGIES IN BRAZIL, AND EXPERIENCES/DIFFICULTIES OF A TRANS COUPLE TO LEGALLY REGISTER THEIR CHILD SUBSIDY THE DEBATE IN THIS ARTICLE.
\end{abstract}

KEYWORDS: KINSHIP; GENDER IDENTITY; FAMILIES. 


\section{INTRODUÇÃO}

Dentro do campo de pesquisa sobre família, especialmente dentro das Ciências Humanas, já parece comum falarmos, a todo momento, a respeito de novidades que florescem e chamam nosso olhar para distintos modos de produzir relações, vínculos, pertencimentos e construir, assim, famílias.

Tentando afastar-se de noções tradicionais - sacralizadas e naturalizadas do que seja isso que chamamos família, diversos trabalhos têm justamente apontado a pluralidade de experiências que se encaixam ou buscam um espaço sobre tal guarda-chuva. Parece, portanto, um tanto repetitivo iniciar outro artigo apontando exatamente a diversidade possível e desejável que circunda e produz tais relações e vínculos afetivos, parentais, amorosos, de filiação e conjugalidade. Entretanto, é ainda pungente a importância de reafirmar a necessária criatividade cultural que marca não só as experiências efetivas de ser e fazer família, mas também e de modo acentuado representações e compreensões acerca da produção de maternidades, paternidades, filiação, gênero, sexualidade e identidades fora de um viés naturalizado.

Deste modo, discutimos neste artigo a relevância dos debates sobre parentesco, gênero e sexualidade em interconexão com o Direito, o Estado e a Medicina. Destacamos a necessidade de reconhecimento de direitos reprodutivos para pessoas não heterossexuais e cisgênero para que possamos pensar sentidos mais amplos de família. Ancoramos, portanto, em um mar de discussões a respeito das múltiplas formas de fazer e ser família, apontando a marginalidade ainda persistente daquelas configurações que despontam da norma sacralizada da família nuclear tradicional ancorada no par binário e sexualmente reprodutivo formado por homem e mulher heterossexual e cisgêneros ${ }^{1}$.

Analisamos neste texto dois eventos importantes para o cenário do parentesco contemporâneo. O primeiro é o caso recente ocorrido no Estado de Santa Catarina/Brasil, em que um hospital se recusou a reconhecer a identidade de gênero de um casal trans durante o nascimento de seu filho ${ }^{2}$. Em decorrência, o casal relatou ter sofrido transfobia no atendimento e complicações com a documentação da criança recém-nascida, pois na declaração de nascido

\footnotetext{
${ }^{1}$ Cisgênero é o termo utilizado para se referir a pessoas que se identificam com o gênero designado no nascimento. Segundo Amara Moira (2017), cisgênero foi uma categoria criada pelo movimento trans para se referir a pessoas não trans.

${ }^{2}$ Disponível em: https://catarinas.info/hospital-e-acusado-de-transfobia-por-nao-respeitar-identidade-de-generode-gestante-e-acompanhante/
} 


\section{Nanduty}

ISSN:2317-8590

vivo, emitida pelo hospital, constava equivocadamente o nome do pai como mãe e o nome da mãe como pai, gerando dificuldade na elaboração da certidão de nascimento do filho do casal.

A confusão transfóbica ocorreu porque entre o casal trans, quem deu à luz foi o pai (homem trans), considerado pelo hospital, portanto, como mãe. Enquanto a mãe (mulher trans) foi definida pela instituição como pai. Ainda que a identidade de gênero do casal tenha sido respeitada, mantendo-se seus nomes de acordo com seus gêneros na documentação interna da instituição, a definição de maternidade e paternidade não recebeu o mesmo respeito. Tal caso é representativo da necessidade de discutirmos mais a fundo sobre parentalidades, reprodução e parentesco de pessoas e casais não heterocisinformados e nos chama a repensar modelos ainda arraigados de corpo/gênero/identidade/parentesco. Destacamos que selecionamos o caso ocorrido e narrado midiaticamente como ponto focal de análise e do qual pinçaremos e analisaremos representações de parentesco amarradas com normas e moralidades heterocis. Não nos debruçamos, deste modo, especificamente em um debate sobre o universo e implicações metodológicas envoltas na análise e contextualização dos veículos de divulgação nos quais o caso foi noticiado. Informamos apenas que o caso foi divulgado em jornais online e televisivos locais e nacionais. Alguns destes veículos de imprensa apresentam algum enfoque em questões de diversidade e gênero, como o portal Catarinas e o Universa do portal de conteúdos da UOL e outros são de ampla circulação nacional sem recortes específicos como o G1, portal de notícias da Rede Globo e canal de televisão NSC de Santa Catarina, filiado também a rede Globo.

O segundo evento analisado trata da recente adição de pessoas transgênero entre pacientes possíveis das tecnologias reprodutivas disponíveis no país e reguladas por normas éticas do Conselho Federal de Medicina (CFM). Esta mudança, ainda que não seja a abertura de um universo antes restrito, marca a necessidade de discussão sobre pluralidade de acesso à filiação e a diferentes modos de produzir famílias, incluindo no rol de possíveis pais, pessoas trans. Todavia, a redação desta normativa que insere pessoas trans entre pacientes possíveis de tais intervenções médico/científicas no campo da reprodução denota, ainda, certa confusão na definição e entendimento social do que seja identidade de gênero e orientação sexual, conforme veremos e analisaremos como mais detalhes no decorrer do artigo. 


\section{FAZER FAMÍLIAS: REPRODUZIR É SEMPRE (RE)PRODUZIR HETEROCISGÊNERIDADE?}

Conforme aponta uma importante bibliografia feminista, especialmente do campo das Ciências Humanas, há vigente em nossas sociedades (ocidentais) uma compreensão da família bastante tradicional e sacralizada (ZAMBRANO, 2006; SOUZA, 2013; BENTO, 2012) que tem por base a naturalização da reprodução sexual como marco do parentesco e, porque não, das relações de gênero e sexualidade. A sacralização da reprodução sexuada dada pelo intercurso sexual entre homem e mulher cisgêneros como base da família, quando transformada em uma ordem natural (de parentesco e também de gênero e sexualidade) acaba por normalizar e edificar um modelo específico e universalizado de família.

Tal ordem imanente, divina, anterior ou natural não se restringe apenas a percepção da família no plano religioso da vida social, mas se desenrola igualmente em outras dimensões que tocam, por exemplo, as visões e definições de família advindas do Estado e presentes na medicina. Este processo de sacralização de um modelo específico de família (casamento e filiação do par heterocis homem e mulher) tem como efeito a desconsideração de tal composição como sócio historicamente construída, portanto terrestre, humana e mutável. No mesmo sentido, diferenciados antropólogos/as têm apontado, por exemplo, que a tendência de se buscar este modelo entendido como universal porque natural da reprodução sexual em outras sociedades marca, na realidade, uma empreitada etnocêntrica (SCHNEIDER, 1980; STRATHERN, 1992).

A compreensão presente nas sociedades ocidentais contemporâneas de que a família é uma de suas instituições mais naturais está, segundo Zambrano (2006), ancorada na sua realidade biológica de fundo: a conjunção entre óvulo e espermatozoide produz bebês. Logo, um homem cisgênero e uma mulher cisgênero produzem crianças e formam a família nuclear base. De tal concepção emerge também a facilidade com que nós, ao sobrepujar a biologia como referencial, estendemos essa compreensão de família ao início dos tempos, a tomando como célula fundadora da sociedade e sustentáculo essencial de sua continuidade. Naturalizamos, assim, este modelo reprodutivo como o único e verdadeiro marco da produção de pessoas e vínculos legítimos de parentesco. Todavia, a compreensão de que a biologia é o refúgio significativo da verdade sobre humanos reside em um certo momento histórico em que essa área do conhecimento passa a ser definitiva na compreensão e definição ontológica do humano (MARTINS, 2004). 


\section{Nanduty}

ISSN:2317-8590

Esse modelo de pensamento ancorado na biologia como verdade irredutível que se entrelaça com uma sacralizada noção de natureza informa a construção de um modelo de pensamento dominante cujas dissidências ou escapes são rapidamente vetados com coro de antinaturais, monstruosos ou pecaminosos. Segundo Thomas Laqueur há no período do Iluminismo uma transformação epistemológica que assenta uma compreensão da natureza como uma base física da realidade, momento no qual "o mundo físico - o corpo - aparece como real" (2001:18) enquanto a dimensão social desponta como um epifenômeno. Atrelado à natureza, o corpo estabilizado, sexuado e a-histórico- a biologia- torna-se a base do mundo social (LUNA, 2007). Assim, não é de estranhar que o apelo a filiação natural seja aquela dada por uma noção sexuada da reprodução com base na dualidade corporal. A biologia, torna-se assim a ancoragem de todo um modelo cultural de relações de pertencimento, proximidade, afeto e sexualidade normatizados culturalmente, mas percebidos como naturais. Falamos, portanto, de uma moralidade que é naturalizada na sombra da biologia (verdade imutável) como proteção.

Ainda assim, aprendemos com Marilyn Strathern (1992), Sara Franklin (2001), Naara Luna (2007), Marlene Tamanini (2009) e David Schneider (1980) que essa tomada da biologia como referência de verdade, longe de ser uma ancoragem em algo verídico é parte de uma compreensão social que busca se estabelecer com força de alicerce inquestionável no mundo ocidental. É fundamental entender que é a cultura que inventa a biologia e é a ciência quem a elabora, dentro dos pressupostos culturais na qual se inscreve e, portanto, esta última não deve servir de pano de fundo para compreensão de modelos e relações de parentesco.

O modelo reprodutivo de parentesco, cujo parâmetro é um modelo que tem na relação sexual seu símbolo fundador, como nos informa David Schneider (1980), não encontra eco afora um pedaço particular do mundo ocidental. Existem variadas formas de pensar a reprodução, a filiação e os modos de conectar pessoas, gerar parentes e construir famílias. As diferenças nos moldes de fazer e pensar família e parentesco são marcadas culturalmente, temporalmente e também geograficamente. Porém, ainda que existam diferentes experiências e muitas etnografias atestando justamente as variadas compreensões de parentesco ao contorno do mundo, persiste, entre nós, uma compreensão arraigada do parentesco e família como aquele domínio duro da natureza biológica da reprodução sexuada e nada mais.

Em consonância, expressa-se em nossa sociedade um modelo de filiação que prescreve uma norma de bilateralidade (FINE, 2013) ancorada na heterocisnormatividade. Ou seja, vigora 


\section{Nanduty \\ ISSN:2317-8590}

a compreensão de que uma criança é fruto/filha de apenas um pai e uma mãe, que são aqueles com quem partilha sua genética/biologia/sangue ${ }^{3}$. Isso define, no plano da vida social, que existem pais 'verdadeiros' para cada criança (aqueles dois que partilham com ela sua carga genética ou biológica). Nesse processo se atesta a incontestável legitimidade e reconhecimento da existência de um único pai e uma única mãe como base da reprodução e assim, da família. Outras formas familiares, existentes aos montes em outras sociedades, tornam-se menos valorizadas, menos verdadeiras e são muitas vezes questionadas ou ironizadas como desconhecimento da verdade reprodutiva ou da ciência.

Ainda que estejamos falando de um modelo ocidental de família naturalizada, coexistem em nosso universo diversas formas de sentir-se família e parente. Especialmente com as transformações sociais que atingem o ocidente após a década de 1960, há uma recomposição do cenário tradicional da família nuclear monogâmica. Divórcios, pílula anticoncepcional, tecnologias de reprodução humana e uma maior abertura às identidades e vivências LGBTQIA+ transformaram também o panorama da vida social e das composições familiares possíveis e desejáveis.

Nestes cenários, categorias como afeto, escolha, amizade, convivência, conexão e mutualidade começam a despontar como pesos que produzem/espessam relações e vínculos entre pessoas que se sentem família para além da hegemônica noção dos laços e vínculos familiares dados pelo partilhar biologia. Vigora, assim, um partilhar de concepções sobre famílias que ora tendem a uma visão mais engessada da natureza, ora apelam a noções como o afeto e a intenção como marcos de sua constituição. Todavia, é mister lembrar que no plano do reconhecimento social e legal das variadas formas familiares existentes, ainda persiste ao fundo indagações e dúvidas a respeito da legitimidade do afeto e intenção como amarras de parentesco válidas e fortes quando postas ao lado da biogenética como definição de família e vínculos de parentesco últimos.

É desta forma que muitas famílias que se formam para além do modelo pai, mãe e filhos deparam-se tantas vezes com questionamentos acerca das conexões presentes em suas famílias. Em famílias com duas mães, por exemplo, indagações como: quem é a mãe verdadeira? Onde está o pai? Como fica o bem-estar da criança criada nesta família? São perguntas recorrentemente postas aos casais. Tais dúvidas recorrentemente endereçadas a famílias não

\footnotetext{
${ }^{3}$ Vejam que para o campo do parentesco a distinção entre essas dimensões importa, todavia aqui iremos tomá-las como equivalente e resumidas a noção de biologia.
} 


\section{Nanduty}

ISSN:2317-8590

heterossexuais e não somente às famílias com duas mães, trazem discussões a respeito do imaginário arraigado da biologia e da bilateralidade baseada na alteridade sexual como pressuposto da filiação e família, noções que precisam ser alargadas para compor um cenário mais plural de famílias.

No contexto das famílias homoparentais, por exemplo, há a necessidade de reinvenção de termos de parentesco para que abarquem as experiências vividas. Afinal, como chamar cada mãe ou pai? Qual lugar cada mulher ou homem irá ocupar na família? Quem será reconhecida/o legalmente e socialmente como "A mãe" ou "O pai"? Como se estabelecem duas maternidades ou paternidades que tenham o mesmo peso frente a hipervalorização da biogenética na produção de vínculos de parentesco e na formação da família? Como fica, na construção da família a mãe que não gesta e como fica o pai que não tem seu DNA presente no fazer filhos? ${ }^{4}$

Falamos aqui, nestes exemplos, de crianças que são geradas por casais homossexuais no intuito de serem eles a família nuclear da qual emergem filhos. Não de crianças que vem de relacionamentos anteriores. Sabemos que a possibilidade de aceder a procedimentos de reprodução assistida permite tal caminho: filhos de casais homossexuais cisgêneros sem um terceiro (uma mãe nos casos de dois pais ou um pai no caso de duas mães) implicado. Ao recorrer a tecnologias como a doação de gametas ou à gravidezes de substituição, é possível driblar alguns caminhos da reprodução sexual, produzindo gravidezes com inseminações artificiais. Nestas trilhas vão se construindo estratégias para apagar e afastar da composição familiar a presença (sobretudo o vínculo de parentesco em potencial) do doador de sêmen, da doadora de óvulos e/ou da mulher que gesta em casos de gestação de substituição para casais formados por homens. As possibilidades são variadas e acenam para estratégias de parentesco colocadas em ação em extensas e reflexivas negociações. Os caminhos para que os vínculos produzidos desconsiderem eventos que poderiam defini-los, como a biologia e genética dadas pelo DNA presente em óvulos ou Sêmen doados ou ainda através do gestar presente nas gravidezes de substituição implicam ações que valorizam outros elementos na produção de laços de parentesco. Nestes contextos, diferentes casais elaboram diferentes caminhos para pinçar o que deverá ser definitivo na produção de paternidades e maternidades para além da habitual norma heterocisgênera de óvulo e gravidez = mãe e sêmen = pai. Observamos, afinal

\footnotetext{
${ }^{4}$ No Brasil, a regra da presunção da paternidade do marido/companheiro na constância de uma relação conjugal estável, seja através da união estável ou do casamento, faz com que o filho gerado pela esposa/companheira seja reconhecido filha/o do homem, independente da verificação da filiação genética/biológica.
} 


\section{Nanduty}

ISSN:2317-8590

que produzir vínculos de parentesco não é um processo tão natural como se pretende (THOMPSON, 2005).

Contudo, poder fazer filhos (especialmente através de tecnologias reprodutivas que viabilizam a desvinculação entre ato sexual heterocisgênero e reprodução) não encerra a discussão sobre família e parentesco para além do modelo tradicional. Após o nascimento das crianças em famílias não hetericisgêneras, ainda há pela frente um caminho no sentido do reconhecimento social e legal da família dentro das identidades e orientações sexuais desejadas e fora da norma heterocis vigente.

Neste sentido, voltamos a discussão para as famílias formadas por pessoas trans para pensarmos a maneira como compreensões a respeito da natureza da reprodução, nesta lógica ancorada em uma visão naturalizante da reprodução sexual, aporta percepções essencializadas de identidades de gênero e orientação sexual. Vale ressaltar que ao falarmos de famílias compostas por pais trans, caminhamos por terrenos de dificuldades distintas daquelas impostas às famílias formadas por dois pais ou duas mães cisgêneros e homossexuais.

Se antes estávamos pontuando os questionamentos que a presença de duas mães ou dois pais pode trazer para o formato naturalizado da família como aquele dado pela presença de pai, mãe e filhos, falaremos agora de composições familiares distintas do modelo tradicional sacralizado, mas que não necessariamente escapam desta configuração dada pela existência de pai, mãe e filho/a.

\section{TRANSFOBIA E PARENTESCO: O QUE A DIFICULDADE EM DEFINIR MATERNIDADE E PATERNIDADE NOS ENSINAM SOBRE FAMÍLIA E IDENTIDADE DE GÊNERO}

Em fevereiro de 2021 ganhou notoriedade na mídia brasileira, a triste notícia de transfobia sofrida por um casal no momento do nascimento de seu filho ${ }^{5}$. Como é praxe em toda internação, ao dar entrada no hospital em meio ao trabalho de parto do gestante, o casal apresentou seus documentos, onde constam seus nomes e identidades de gênero retificados. Respeitados, os nomes foram registrados e utilizados pelas equipes médicas e na identificação interna do paciente gestante e do bebê recém-nascido.

\footnotetext{
${ }^{5}$ Disponível em: https://catarinas.info/hospital-e-acusado-de-transfobia-por-nao-respeitar-identidade-de-generode-gestante-e-acompanhante/.
} 


\section{Nanduty}

ISSN:2317-8590

A transfobia não se iniciou, deste modo, no desrespeito ao nome ou gênero marcador da identidade do paciente, como é o mais habitual e poderíamos imaginar. A confusão se instalou no momento em que foi necessário acionar categorias de parentesco, como mãe e pai para referir-se ao paciente e ao bebê. Portanto, não se tratou de uma transfobia ligada exclusivamente à individualidade do sujeito (cujo nome e identidade de gênero foram respeitados), mas vinculada ao lugar e definição de cada indivíduo na composição familiar.

Derick, homem trans gestante, relatou em entrevistas que circularam na mídia, que durante sua estadia no hospital apesar de ter sido chamado e reconhecido como Derick, homem, foi repetidas vezes identificado e chamado pela equipe médica de mãe. De fato, na pulserinha de identificação de seu filho recém-nascido, que aparece em fotos nas reportagens sobre o evento, seu nome masculino apareceu identificado como mãe, Terra, mulher trans companheira de Derik, afirmou ainda que a despeito de sua identidade de gênero, foi definida como pai pela equipe da maternidade, informações que pudemos acessar ao assistir entrevista realizada com o casal e disponível online ${ }^{6}$.

Não bastasse a transfobia presente na experiência do parto, e no entendimento da equipe médica de Derick como mãe e Terra como pai de seu filho, o casal ainda teve uma outra surpresa. Ao receber do hospital a declaração de nascido vivo de seu filho se deparou com a consolidação do erro transfóbico assentado no equívoco em estabelecer a parentalidade do casal: Terra apareceu na declaração como pai e Derick novamente como mãe. É salutar informar que segundo Terra, tal definição foi tomada pelo hospital sem consulta alguma ao modo como o casal se definia em relação ao filho em termos de parentesco, ou seja, a maternidade e paternidade do casal foi presumida e definida pelo hospital, conforme afirmou a advogada do casal Ana Cunha Rodrigues ao jornal $\mathrm{Nd}+{ }^{7}$ em matéria escrita por Juliane Guerreiro e publicada em 16 de fevereiro de 2021.

Ainda segundo tal matéria jornalística, em posse do documento atestando o nascimento da criança, o casal tentou proceder o registro do filho em cartório, solicitando a inversão dos lugares de mãe e pai presentes na declaração emitida pelo hospital, o pedido foi rejeitado. Frente a tal impasse, o casal tentou que o hospital retificasse o documento errado, mas não obteve sucesso. Diante dos insucessos nas tratativas com o hospital e cartório para reverter o equívoco,

\footnotetext{
6 Disponível em: https://g1.globo.com/sc/santa-catarina/noticia/2021/02/09/casal-alega-transfobia-apos-naoconseguir-registrar-filho-por-causa-de-certidao-preenchida-errada-em-maternidade-de-sc.ghtml.

${ }^{7}$ Pertencente ao portal de notícias ND, conglomerado midiático sediado em Florianópolis/SC.
} 


\section{Nanduty}

o casal se viu impelido a buscar uma advogada. Entraram, em consequência, com uma ação contra o hospital e transcorridos vinte dias do nascimento da criança, o casal finalmente conseguiu registrá-lo, após uma liminar parcial do Tribunal de Justiça de Santa Catarina permitir o registro com a filiação acertada.

Para além de evidenciar a constante transfobia vivenciada pelas pessoas trans no Brasil, e experienciada pelo casal ao ter confundida sua identidade de gênero no hospital em que nasceu seu filho, o que este caso nos revela é o peso de uma noção naturalizada de reprodução e parentesco na percepção e entendimento de identidade de gênero em um viés essencializado.

O que queremos dizer com isso? Bom, que apesar da compreensão de que pessoas trans podem ter seus nomes e identidade de gênero retificadas em seus documentos no Brasil, ainda não há uma transformação a respeito de noções sedimentadas do que define e faz uma mulher e um homem em termos de reprodução. É exemplo disso a resposta dada pelo Hospital ao ser questionado sobre o evento por Júlia V. Kurtz em matéria para o portal Universia:

Em nota para Universa, o Hospital e Maternidade Jaraguá afirma que seguiu as orientações do Ministério da Saúde para o preenchimento do DNV, que exige que os dados da parturiente sejam tratados como mãe (KURTZ, 2021).

Podemos dizer, tomando o caso citado como exemplo, que persiste a compreensão de que é o aparelho reprodutor, tantas vezes definido como genital, que dá a definição última da identidade de cada pessoa. Se é possível que nome e gênero se alterem e permaneçam respeitados no campo da vida social, nos documentos e no acesso a direitos diversos, no campo da medicina e da saúde o debate ainda não está consolidado. Como fica evidente na declaração do hospital ao referenciar a necessidade da parturiente ser definida como mãe, é o corpo quem pode ditar a definição última do parentesco e da identidade de gênero inquestionável (mãe/feminina) que decorre do evento corpo/parto.

Derick, ao entrar em um hospital gestante, ainda que seja homem, é rapidamente transformado em mãe. Seu útero parece lhe conferir quase que instantaneamente, aos olhos da equipe médica, a definição ontológica de seu ser: mulher. Não parece haver problema na existência de uma mãe com nome masculino, o problema parece justamente ser um pai gestar e parir seu filho. O corpo, entendido aqui a partir de definições binárias e arraigadas do que sejam suas partes femininas e masculinas, torna-se ancoragem das definições médicas e hospitalares convencionais e não há dúvidas ou espaço para debate, pariu é, ainda que homem, mãe. 


\section{Nanduty}

ISSN:2317-8590

A diferença do que ocorre com os casais homossexuais cisgêneros, a equipe médica não aporta dúvidas sobre quem seria o verdadeiro pai ou a verdadeira mãe. A questão que se coloca é de outra ordem. Afinal, o que produz um pai e o que produz uma mãe? As dúvidas, tantas vezes acionadas e circulantes nas experiências de casais homossexuais a respeito de como eles produzem duas mães ou dois pais, ou ainda, como gerem a ausência de parte entendida como fundamental na produção da família baseada na alteridade sexual sequer é levantada no caso de Derick e Terra. O hospital, de frente à heterossexualidade pressupõe a existência de paternidade e maternidade ao casal trans sem considerar suas identidades. As habituais chaves de definição de pertencimentos de parentesco são acionadas: quem gesta e quem empresta seu óvulo para a formação do bebê é mãe, quem não gesta, mas fornece o espermatozoide é pai. Não há espaço para que experiências conjugais marcadas pela alteridade de gênero, portanto heterossexuais, sejam entendidas para além da norma cisgênera e para que casais que produzem seus filhos de modo sexual, ainda que não cisgeneramente, vejam suas identidades prevalecerem sob leituras essencializadas de seus corpos e gametas. Aqui, não apenas a biologia é tomada como referente de definições de família e apelativos de parentesco (é pai e mãe quem doa material genético), mas sobretudo, uma visão engessada e ciscentrada da biologia é que é acionada de forma exemplar (é mãe quem dá à luz, é pai quem fornece espermatozoides). Pais e mães não são apenas aqueles que fornecem material genético, mas sobretudo são definidos a partir de um tipo específico de gameta que transporta não só material genético, mas lugares de parentesco e gênero.

Você pode ser homem a despeito de sua genital, mas não há como ser pai a despeito de sua gestação. Essa não é uma questão menor. Há muito se vem falando da necessária desconexão entre parentesco e corpo biológico para compreender a pluralidade possível e desejada de configurações familiares existentes. A entrada das tecnologias reprodutivas no campo da reprodução atenta justamente para importância de pensar tais dimensões como distintas, separando sexo e reprodução. Entretanto, cabe questionar: de que corpo biológico se deseja afastar o parentesco para estabelecer visões mais plurais de família? O caso citado nos direciona para a necessária questão da reprodução entendida não apenas em seu caráter natural e biológico como amarra essencializada do parentesco, mas informa, nomeadamente a respeito das leituras vigentes da biologia a partir de um olhar heterociscêntrico. Ou seja, aquele que define que óvulo e espermatozoides fazem pai e mãe, mas não de forma criativa. Óvulo faz mãe e espermatozoide faz pai, os termos de parentesco não se casam apenas com biologia, senão 


\section{Nanduty}

ISSN:2317-8590

com um sentido estreito da biologia. Assim, não vale apenas afastar-nos de noções biológicas para dar vasão a pluralidade de conexões e vínculos que podem moldar, ao sabor das intencionalidades e afetos, as relações familiares. É necessário também atentar para os modos como criamos e naturalizamos um sentido único de biologia e natureza, partindo para isso exclusivamente das noções de corpo e reprodução heterocisinformados. Afinal, é possível que um encontro sexual produza gravidez e filhos sem que defina de modo cisgênero quem é pai e quem é mãe.

Maternidade e paternidade não se fazem necessariamente de conexões biogenéticas. Antes, são experiências construídas e embasadas em uma sorte variada de eventos. Cuidado, afeto, intenção e convivência são colocados a toda hora como valores que definem a ação parental e produzem mães e pais tal como gravidezes ou DNA. O corpo não é o referente último do parentesco, entendido como um processo sociocultural de estabelecimento de vínculos, que se dão conforme estratégias, invenções criativas que conectam pessoas, que produzem sentidos de descendência, de pertencimento coletivo e de família.

O parentesco é um campo plástico, de rearranjos possíveis, de formatos variados, perpassado sim por biologia, mas também por definições culturais e reconhecimentos sociais do que pode nos emparentar. Todavia, parece inquestionável o peso da biologia e do corpo cisgênero como referencial último de toda inventividade possível. Não parece ainda ser possível, ou ao menos tarefa fácil, reinventar a própria biologia, produzindo conexões e famílias nas quais óvulos fazem pai e sêmen faz mãe. A natureza essencializada da maternidade e paternidade vinculados a órgãos e gametas específicos parece não dar brechas para negociações e intencionalidades colocadas em ação por pessoas não heterocisgêneras.

Se o afeto pode marcar vivências outras e produzir famílias que já ganham reconhecimento e legitimidade social, ainda resta a difícil tarefa de significar o corpo e suas partes de modos plurais, deslocar essencialismos biológicos a partir da própria biologia e colocar o próprio modelo reprodutivo heterossexual em questão a partir de lógicas e leituras não ciscêntricas.

Em consonância, destacamos que no dia 28 de junho de 2021, dia internacional do orgulho LGBTQIA+, o ministro do Supremo Tribunal Federal, Gilmar Mendes, deferiu, através de uma liminar, que o Ministério da Saúde adote medidas respeitosas as identidades de gênero no campo do atendimento e acolhimento em saúde. Com tal determinação, dotou-se o Ministério da Saúde de um prazo de trinta dias para adequar o sistema interno do Sistema Único 
de Saúde (SUS) para o respeito a identidade de gênero e, ponto que nos interessa em particular neste artigo, determinou a alteração do documento de declaração de nascido vivo. Tais medidas cumprem importância, de acordo com o próprio texto do documento, pois negativas de preenchimento da declaração de nascido vivo em desacordo com as identidades de gênero dos pais são violações dos direitos sexuais e reprodutivos da comunidade trans. Segundo documento liminar:

Quanto à Declaração de Nascido Vivo: ii.a. Determinar ao Ministério da Saúde, por meio da Secretaria de Vigilância da Saúde (SVS-MS), que, no prazo de 30 (trinta) dias: proceda à alteração do layout da DNV para que faça constar da declaração a categoria "parturiente", independente dos nomes dos genitores de acordo com sua identidade de gênero. Isso possibilitará, ao mesmo tempo, o recolhimento de dados para a formulação de políticas públicas pertinentes e o respeito à auto declaração de gênero dos ascendentes; ii.b. Ordenar ao Ministério da Saúde que, no prazo de 30 (trinta) dias: estabeleça diretrizes para, em conjunto com as Secretarias de Estado da Saúde e com as Secretarias Municipais de Saúde, gestoras estaduais do SIM e do SINASC, orientar as unidades notificadoras a alimentarem os registros pertinentes considerando a categoria "parturiente", independente dos nomes dos genitores de acordo com sua identidade de gênero (ADPF 787, 2021: 36)

A declaração de nascido vivo é o primeiro documento de registro do nascimento e vida de um bebê, documento que gerou toda a confusão transfóbica de que foram alvo o casal trans Derick e Terra citado anteriormente. Segundo a nova determinação, tal declaração deve passar a incluir a categoria "parturiente", ou seja, a pessoa que pariu deve ser identificada sem exigência de ser automaticamente classificada como pai ou mãe. Já os campos de maternidade e paternidade devem ser reservados para aqueles que serão os representantes legais da criança e que terão vínculos de parentalidade com a mesma (definindo-se, então como pai ou mãe). Essa é uma mudança significativa que abandona a compreensão a respeito do que é ou faz paternidade e maternidade baseada no sexo/aparelho reprodutivo para instaurar uma noção assentada nos lugares de gênero autodeterminados por sujeitos e sujeitas que produzem, por consequência, suas localizações em termos de apelativos de parentesco: mãe ou pai.

Através do caso apresentado aqui, refletimos sobre o que acontece quando se misturam identidades de gênero, sexualidade e família. Como questão central neste debate talvez possamos apontar como relevante a forma como reconhecemos quem é pai e quem é mãe. Observamos que os termos de parentesco ainda se misturam com a naturalizada conexão entre sexo e gênero, expressa sobretudo entre sexo e lugar no parentesco/definição de parentesco. Ainda que sexo e gênero possam ser desvinculados, sexo e parentesco parecem mais difícil de serem dissociados no campo da saúde e medicina.

É necessário desvincular identidades de uma leitura engessada de corpo/organismo e entendê-las como construções sociais, tema e engajamento caro aos debates e movimentos 


\section{Nanduty}

ISSN:2317-8590

trans. Apenas desvinculando tais concepções é que poderemos compreender como as dimensões de gênero e sexualidade são também construídas dentro de uma lógica cisheterocentradas de parentesco que parece ainda passar silenciada.

\section{A REPRODUÇÃO HUMANA ASSISTIDA: RESOLUÇÔES NORMATIVAS DO CFM E DEFINIÇÕES DE IDENTIDADE DE GÊNERO, ORIENTAÇÃO SEXUAL E PARENTESCO}

Em $2020^{8}$, o Conselho Federal de Medicina publicou uma atualização da já conhecida Resolução normativa 2.168 de 2017 que regulamenta o acesso às tecnologias reprodutivas no Brasil. No país, cabe lembrar, não há legislação específica sobre este tema, restando à própria área médica regimentar suas investidas e ações neste campo. É assim que desde os anos 1990 existem no Brasil resoluções normativas produzidas e atualizadas pelo Conselho Federal de Medicina que ditam as balizas da aplicação de tecnologias voltadas a reprodução humana.

Neste cenário, considerações a respeito da família compõem o rol das discussões que tocam a área médica voltada a reprodução em laboratório. Afinal, é preciso refletir a quem e em que casos se destinam estes procedimentos, questões amplamente debatidas pela teoria feminista, em especial por aquelas e aqueles pesquisadores voltados aos debates sobre ciência e saúde.

Muitos países, dispostos a legislar sobre o tema da família e da reprodução humana em laboratório, possuem leis bastante restritivas sobre o tema, como é o caso de França, Alemanha, Itália e Suíça, conforme esclarece Virginie Rozée Gomez (2015). Na contramão, o Brasil desponta como um país aberto e inclusivo no que toca o acesso plural a tais procedimentos. No Brasil, assim como em países como os EUA, Japão e Índia, as regulações das tecnologias voltadas a reprodução trata-se de normas não legais, aqui editadas pelo Conselho Federal de Medicina e talvez por esse motivo, mais maleáveis.

No ano de 2013, o CFM publicou a terceira versão da normativa sobre reprodução assistida existente no Brasil. Nela, mostrou avanço e acompanhamento das demandas sociais, em particular aquelas que tocam o reconhecimento legal dos casais de pessoas homossexuais. De fato, a interface reprodução assistida e homoparentalidade conversa de perto com as legislações a respeito do casamento entre pessoas homossexuais. Em 2011, com o julgamento proferido pelo Supremo Tribunal Federal (STF) que decidiu pela aprovação da união estável

\footnotetext{
${ }^{8}$ Em 2021 o Conselho Federal de Medicina edita uma nova versão desta Resolução. Contudo, não há mudanças no tocante ao acesso de pessoas trans às tecnologias reprodutivas.
} 


\section{Nanduty}

ISSN:2317-8590

entre pessoas do mesmo sexo ou do mesmo gênero, abriu um caminho para a concessão de direitos para tais casais. Em suma, estendeu para eles os mesmos direitos já assegurados aos casais heterossexuais, tais como: o direito à adoção, pensões, herança fiscal, imposto de renda, segurança social, benefícios de saúde, imigração, propriedade conjunta e recurso à tecnologias reprodutivas. Abriu-se um caminho efetivo para que casais formados por pessoas do mesmo sexo ou gênero acessassem tais procedimentos e concretizassem seus projetos familiares e de filiação. Tal decisão garantiu o reconhecimento nacional da conjugalidade homossexual como entidade familiar. Ou seja, houve uma equiparação jurídica dos casais formados por pessoas homossexuais ao regime de conjugalidade heterossexual já reconhecido legalmente como união estável em um regime que possibilita a posterior equiparação desta união ao casamento (NICHNIG, 2014). Já em 2013 o Conselho Nacional de Justiça (CNJ) aprovou resolução que obrigou todos os cartórios do país a realizarem a conversão da união estável entre pessoas homossexuais em casamentos, bem como os obrigou a atender a solicitações de casamentos civis entre pessoas não heterossexuais. Apesar da decisão de 2011 do STF, muitos cartórios, tabeliães e juízes seguiam negando o registro das uniões entre pessoas homossexuais com base no Código Civil Brasileiro, que ainda determina que o casamento somente pode ser realizado por um casal, formado por um homem e por uma mulher. De tal modo, a resolução do CNJ botou fim as diferentes possibilidades interpretativas ao obrigar o aceite do casamento civil não hetero e da conversão da união estável em casamento em todo território brasileiro.

Em conformidade com este momento, a Resolução no 2.013 do Conselho Federal de Medicina datada de 2013 modifica seu texto inicial e já em suas considerações de abertura faz menção à necessidade de pôr-se de acordo com as transformações políticas que concerniam os casais formados por pessoas homossexuais e sua instituição enquanto unidade familiar. No texto da resolução lê-se:

\section{RESOLUÇÃO CFM N $2.013 / 2013$}

(Publicada no D.O.U. de 09 de maio de 2013, Seção I, p. 119) REVOGADA por Resolução CFM 2.121/2015.

Adota as normas éticas para a utilização das técnicas de reprodução assistida, anexas à presente resolução, como dispositivo deontológico a ser seguido pelos médicos e revoga a Resolução CFM n ${ }^{\circ} 1.957 / 10$.

O CONSELHO FEDERAL DE MEDICINA, no uso das atribuições conferidas pela Lei $\mathrm{n}^{\circ} 3.268$, de 30 de setembro de 1957, alterada pela Lei $\mathrm{n}^{\circ} 11.000$, de 15 de dezembro de 2004, regulamentada pelo Decreto $\mathrm{n}^{\circ} 44.045$, de 19 de julho de 1958 , e Decreto $\mathrm{n}^{\circ}$ 6.821, de 14 de abril de 2009, e

CONSIDERANDO a importância da infertilidade humana como um problema de saúde, com implicações médicas e psicológicas, e a legitimidade do anseio de superá-la; 


\section{Nanduty}

CONSIDERANDO que o avanço do conhecimento científico já permite solucionar vários casos de problemas de reprodução humana;

CONSIDERANDO que o pleno do Supremo Tribunal Federal, na sessão de julgamento de 5.5.2011, reconheceu e qualificou como entidade familiar a união estável homoafetiva (ADI 4.277 e ADPF 132);

CONSIDERANDO a necessidade de harmonizar o uso destas técnicas com os princípios da ética médica;

CONSIDERANDO, finalmente, o decidido na sessão plenária do Conselho Federal de Medicina realizada em 16 de abril de 2013.

RESOLVE:

Art. $1^{\circ}$ Adotar as normas éticas para a utilização das técnicas de reprodução assistida, anexas à presente resolução, como dispositivo deontológico a ser seguido pelos médicos Art. $2^{\circ}$ Revoga-se a Resolução CFM n ${ }^{\circ} 1.957 / 10$, publicada no D.O.U. de 6 de janeiro de 2011, Seção I, p. 79, e demais disposições em contrário.

Art. $3^{\circ}$ Esta resolução entra em vigor na data de sua publicação.

Brasília, 16 de abril de 2013. (CFM, 2013:s/p) [Grifos nossos]

Assim, dentre as novidades trazidas pela resolução de 2013 realçamos a abertura definitiva do caminho para que casais homossexuais possam ter filhos por meio da reprodução em laboratório. Destaca-se que a consideração a respeito das mudanças no reconhecimento da conjugalidade homossexual também respingou nas definições propostas pela resolução sobre quem são ou poderiam ser os beneficiários destas tecnologias, como fica claro abaixo:

\section{II - PACIENTES DAS TÉCNICAS DE RA:}

1 - Todas as pessoas capazes, que tenham solicitado o procedimento e cuja indicação não se afaste dos limites desta resolução, podem ser receptoras das técnicas de RA desde que os participantes estejam de inteiro acordo e devidamente esclarecidos sobre a mesma, de acordo com a legislação vigente.

2 - É permitido o uso das técnicas de RA para relacionamentos homoafetivos e pessoas solteiras, respeitado o direito da objeção de consciência do médico. (CFM, 2013:s/p) [Grifos nossos].

Este texto de 2013 a respeito dos pacientes alvos das tecnologias reprodutivas sofreu atualização na Resolução 2.121, datada de 2015. Nela adicionou-se aos itens 1 e 2 do inciso IIPacientes das técnicas de RA, o item 3: “3 - É permitida a gestação compartilhada em união homoafetiva feminina em que não exista infertilidade" (CFM, 2015:s/p).

Esta foi uma importante atualização que atingiu em especial os casais formados por mulheres lésbicas cisgênero, que passaram a poder trocar óvulos entre si produzindo a chamada gestação compartilhada. Já na Resolução 2.168 publicada em 2017 e que atualizava a versão de 2015, optou-se por dar uma definição adicional para o que se chamou em 2015 de gestação compartilhada: 
3. É permitida a gestação compartilhada em união homoafetiva feminina em que não exista infertilidade. Considera-se gestação compartilhada a situação em que o embrião obtido a partir da fecundação do(s) oócito(s) de uma mulher é transferido para o útero de sua parceira (CFM, 2017:s/p).

Nota-se, ao longo destas atualizações, uma importante atuação do CFM na tentativa de sempre produzir esclarecimentos e leituras mais acertadas da multiplicidade de experiências e desejos que se incorporam nas demandas por filhos produzidas pela pluralidade de relações conjugais, afetivas e desejos de família existentes. Ao mesmo tempo, importa destacar que trazer registrado em suas normativas a possibilidade de pessoas não heterossexuais acessarem tais tecnologias resulta no reconhecimento das muitas formas de ser e fazer família, tantas vezes deixadas à margem do reconhecimento legal.

Em consonância, em 2020 a Resolução de 2017 sobre novas alterações. Desta vez, na resolução 2.283 de 2020 observamos a entrada de pessoas transgêneros como pacientes possíveis das tecnologias reprodutivas. Em seu novo texto consta:

RESOLVE:

Art. $1^{\circ}$ Alterar a redação do item 2 do inciso II, "Pacientes das técnicas de RA", da Resolução CFM n 2.168/2017, publicada no DOU de 10 de novembro de 2017, Seção I, p. 73, que passará a ser a seguinte:

II. (...)

2. É permitido o uso das técnicas de RA para heterossexuais, homoafetivos e transgêneros. (CFM, 2020:s/p)

No mesmo documento em que apresenta a alteração, o CFM explica sua motivação:

Pelo exposto, ao indicar expressamente sua aplicação a determinados segmentos da população, nomeadamente "homoafetivos" e "pessoas solteiras", a norma poderia ensejar interpretações contraditórias, com a adoção literal do texto, excluindo-por exemplo-pessoas casadas ou heterossexuais, assim como outras categorias ali não expressas, como os transgêneros. Evidenciou-se, deste modo, a necessidade de alteração do texto normativo, de modo a adotar - se nova redação, mais geral e abrangente, que não exclua possíveis interessados na RA, nem permita interpretações heterodoxas que prejudiquem a eficácia da norma. Por esse motivo, passa-se a indicar a técnica para a generalidade das pessoas em sociedade: "heterossexuais, homoafetivos e transgêneros" (CFM, 2020:s/p).

Destacamos que essa alteração é uma importante ação no sentido de garantir um acesso plural às tecnologias reprodutivas, importante vetor de produção e promoção das famílias homoparentais, por exemplo. Fazer referência explícita a população trans como detentora do direito de quando e se desejar poder acessar a tais tecnologias nos informa sobre o reconhecimento das identidades de gênero não cisgênero como produtoras também de famílias 


\section{Nanduty}

ISSN:2317-8590

e de crianças, inscrevendo-se no rol do parentesco intencionado e, que nos casos em que encontrar barreiras, seja pela ausência de alteridade sexual, seja pela infertilidade, possa se concretizar

Todavia, para além de acenarmos apenas para o valioso reconhecimento das pessoas trans como sujeitas e sujeitos também desejáveis entre aqueles que produzem e podem produzir famílias e crianças em nossa sociedade através das tecnologias reprodutivas, esta abertura gerada pela resolução do CFM chama nosso olhar para uma questão outra. Destacamos aqui, em específico, a forma como o texto da resolução foi redigido. Ao abrir o acesso plural a tais tecnologias, a resolução apresenta: "É permitido o uso das técnicas de RA para heterossexuais, homoafetivos e transgêneros" (CFM, 2020:s/p). Ao elencar heterossexuais, homoafetivos e transgêneros como generalidade de pessoas as quais tais tecnologias estão disponíveis, o texto da resolução incorre em um importante equívoco conceitual. Uma mistura de lugares e experiências que também faz eco com o evento de transfobia vivenciado por Derick e sua companheira narrado acima, neste texto.

Vamos por partes. Primeiro que heterossexual é um conceito do campo dos debates e pesquisas sobre sexualidade e define uma orientação sexual, ou seja, fala de um desejo afetivo/sexual, no caso em questão, marcado pela alteridade presente no par: homem e mulher. Tal conceito não se refere à vivência conjugal ou às experiências subjetivas dadas entre as partes do casal. Em contrapartida, aquelas pessoas que expressam desejo afetivo/sexual fora desta alteridade são conceitualmente definidas como homossexuais e não como homoafetivos.

O uso do termo homoafetividade parece ser uma singularidade brasileira e está, como podemos ver, presente em diversos documentos oficiais (COSTA; NARDI, 2015), tendo até mesmo entrado para o dicionário recentemente. Como expresso no próprio conceito, o afeto parece ser o carro chefe da elaboração desta noção. Tendo origem no campo jurídico, marcadamente dentro do âmbito do direito da família, tal conceito alude a relações conjugais de pessoas do mesmo gênero. Foi cunhado pela advogada e desembargadora aposentada do Tribunal de Justiça do Rio Grande do Sul, Maria Berenice Dias (2000) numa tentativa de introduzir as uniões de pessoas do mesmo gênero dentro do reconhecimento legal e social. $\mathrm{O}$ termo busca jogar luz sobre a dimensão afetiva presente nas relações conjugais ao tirar de destaque a dimensão sexual presente no conceito de homossexualidade, que versa, por sua vez, sobre uma orientação sexual. Esse deslocamento (homoSEXUAL para homoAFETIVO) 


\section{Nanduty}

ISSN:2317-8590

permitiu o reconhecimento do afeto como um elemento central do vínculo familiar, retirando da naturalidade do encontro heterossexual a exclusividade da capacidade produtora de famílias.

Ainda que seja um conceito importante para pensarmos famílias, homoafetividade ou homoafetivo não diz respeito a pessoas ou orientações sexuais e sim a subjetividades pungentes em relações conjugais. Logo, apesar de carregar avanços no que tange a uma percepção do direito brasileiro e do Estado frente ao tema do acesso às tecnologias reprodutivas e das possibilidades familiares baseadas em casais do mesmo sexo ou gênero, o termo homoafetividade não escapa de severas críticas.

Indo ainda mais longe, a atualização de 2020 da resolução normativa do CFM apresenta ao lado do termo heterossexuais e homoafetivos, o termo transgêneros. De saída verifica-se uma confusão entre orientação sexual, experiências subjetivas de conjugalidade e identidade de gênero, postas no texto lado a lado como se falassem de uma mesma experiência. Hetero ou homossexual são conceitos que falam sobre o desejo afetivo e/ou sexual de cada pessoa. Homoafetivo é um conceito usado especialmente no campo do direito visando minar preconceitos associados às identidades homossexuais (entendidas tantas vezes como promíscuas). Tal conceito localiza, desta forma, experiências homossexuais no campo da afetividade e não da sexualidade, facilitando a conjugação entre práticas e vivências homossexuais e famílias. Já transgênero, travesti, transexual e cisgênero são conceitos utilizados em referência a identidade de gênero, nada tendo a ver com a dimensão do desejo afetivo e/ou sexual por outrem, ou com a experiências conjugais baseadas em afeto, pois falam da percepção individual de cada pessoa a respeito de si mesma. Neste sentido, Berenice Bento informa que é preciso que a gente consiga distinguir de modo claro as categorias identidade de gênero e sexualidade (orientação sexual):

É importante ressaltar que a identidade de gênero e a identidade sexual são dois marcadores da diferença que não se confundem. Quando eu digo "sou uma mulher", não estou revelando absolutamente nada sobre minha sexualidade, práticas sexuais e desejos (BENTO, 2012:278)

Esta separação de marcadores importa por aportar compreensões e reconhecimentos diferentes no campo da família e parentesco. Observamos, por exemplo, que entre Derick, Terra e a definição de quem seria pai ou mãe do filho gestado pelo casal, houve justamente uma confusão entre as distintas dimensões da orientação sexual e identidade de gênero. Afinal, Derick e Terra são pessoas transgênero, mas que expressam orientação sexual heterossexual. 


\section{Nanduty}

ISSN:2317-8590

Podem, deste modo, produzir crianças de forma sexual, não obedecendo, por isso, a lógica cisgênera de heterossexualidade. Configuram, assim, uma família heterossexual trans na qual existe um pai que gesta e uma mãe que doa seu sêmen para produção do filho.

Essas distintas categorias de identidade de gênero e sexualidade produzem compreensões particulares e importantes a respeito do parentesco e dos modos como estabelecemos paternidade e maternidade. As famílias trans, podemos dizer, ajuntam uma dimensão outra ao debate sobre homoparentalidade de pessoas cisgênero haja vista falarem de outro lugar reprodutivo, identitário e de reconhecimento social. Trazem à tona, por exemplo, a necessidade de pensar a existência plural das identidades e orientações sexuais. Há, vale ressaltar, a heterossexualidade trans que pode existir com ou sem alteridade sexual, ao mesmo tempo, há a homossexualidade trans que pode existir com ou sem alteridade sexual dos/as parceiros/as. Tal relação variada entre identidade de gênero e orientação sexual acena também para formas de violências e fobias distintas enfrentadas pelos/as sujeitos/as, casais ou famílias. Tais entrelaces entre orientação sexual e identidade de gênero precisam ser pontuadas a partir de suas especificidades e a partir do que suas experiências e identidades acionam no campo do parentesco, do discurso médico que toca os temas da reprodução e corpo e também, na esfera legal do reconhecimento das relações parenteais ensejadas de forma sexual ou via tecnologias.

De tal modo, consideramos a importância de pontuar o equívoco conceitual que os textos que balizam as tecnologias reprodutivas parecem carregar. Ainda que a nova resolução do CFM sinalize um movimento que busca avançar na garantia de direitos sexuais e reprodutivos da população LGBTQIA+ no Brasil, é preciso que se aprofunde, separe e organize as diferentes dimensões que performatizam a produção das parentalidades hetero ou homocisgêneras e hetero ou homo-trasngêneras para que suas consequências no campo de definições de parentesco não sirvam às normatizações essencialistas outras vezes.

Afinal, como nos ensina Fernanda Cardozo (2007) ao falar de relações de parentesco de mulheres travestis, não só o gênero é performativizado, mas também a posição na organização e na estrutura de parentesco. Garantir o reconhecimento da pluralidade que inscreve o fazer e viver parentalidades trans permite, em consequência, o reconhecimento paulatino da diversidade de caminhos possíveis para identidades e performances de gênero e sexualidade. 


\section{REFERÊNCIAS}

BRASIL. Supremo Tribunal Federal. 2021. Arguição de Descumprimento de Preceito Fundamental ADPF) $\mathrm{n}^{\mathrm{o}} 787$ MC /Brasília, 28 de junho de 2021. In: http://www.stf.jus.br/arquivo/cms/noticiaNoticiaStf/anexo/ADPF787.pdf (acessado em $20 \mathrm{de}$ fevereiro de 2021).

BRASIL. Conselho Nacional de Justiça. 2021. Resolução na 175 , de 14 de maio de 2013. Dispõe sobre a habilitação, celebração de casamento civil, ou de conversão de união estável em casamento, entre pessoas de mesmo sexo. Brasília, DF. In: http://www.cnj.jus.br/images/imprensa/resolu\%C3\%A7\%C3\%A3o_n_175.pdf (acessado em 20 de fevereiro de 2021).

CARDOZO, Fernanda. 2007. "Performatividades de gênero, performatividades de parentesco: notas de um estudo com travestis e suas famílias na cidade de Florianópolis/SC". In: GROSSI, Miriam; UZIEL, Anna Paula; MELlO, Luiz (orgs). Conjugalidades, parentalidades e identidades lésbicas, gays e travestis. Rio de Janeiro: Garamond, p. 233-252.

CONSELHO FEDERAL DE MEDICINA. 1992. Resolução CFM, n. 1.358. Brasília-DF. CONSELHO FEDERAL DE MEDICINA. 2010. Resolução CFM, n. 1.957. Brasília-DF. CONSELHO FEDERAL DE MEDICINA.2013. Resolução CFM, n. 2.013. Brasília-DF. CONSELHO FEDERAL DE MEDICINA. 2015. Resolução CFM, n. 2.121. Brasília-DF. CONSELHO FEDERAL DE MEDICINA. 2017. Resolução CFM, n. 2.168. Brasília-DF. CONSELHO FEDERAL DE MEDICINA.2020. Resolução CFM, n. 2.283. Brasília-DF.

COSTA, Angelo Brandelli; NARDI, Henrique Caetano. 2015. "O casamento "homoafetivo" e a política da sexualidade: implicações do afeto como justificativa das uniões de pessoas do mesmo sexo". Revista Estudos Feministas, Florianópolis, v. 23, n. 1: 137-150. In: https://periodicos.ufsc.br/index.php/ref/article/view/37467 (acessado em 02 de fevereiro de 2021).

DIAS, Maria Berenice. 2000. União homossexual: o preconceito e a justiça. Porto Alegre: Livraria do Advogado.

FINE, Agnès. 2013. "Parenté: liens de sang et liens de coeur". In: BEDIN, Véronique; FOURNIER, Martine. (dir.) La parenté en question(s). Paris: Sciences Humaines Éditions, p.40-49.

FRANKLIN, Sarah. 2001. "Biologization revisited: kinship theory in the context of the new biologies". In: FRANKLIN, Sarah; MACKINNON, Susan (orgs.). Relative Values: reconfiguring kinship studies. Durham: Duke University Press, p.302-325.

GOMEZ, Virginie Rozée. 2015. "Les normes de la maternité en France à l'épreuve du recours transnational de l'assistance médicale à la procréation". Recherches familiales, n. 12: 43-55.

GUZZO, Morgani. 2021. "Hospital é acusado de transfobia por não respeitar identidade de gênero de gestante e acompanhante". Catarinas. In: https://catarinas.info/hospital-e-acusadode-transfobia-por-nao-respeitar-identidade-de-genero-de-gestante-e-acompanhante/.

(Acessado em 17 de fevereiro de 2021).

KURTZ, Júlia V.SC: 2021. "Casal denuncia hospital por transfobia após nomes trocados em certidão". Universa Uol, In: https://www.uol.com.br/universa/noticias/redacao/2021/02/09/sccasal-denuncia-hospital-por-transfobia-apos-nomes-trocados-em-

certidao.htm?cmpid=copiaecola\&cmpid=copiaecola (acessado em 17 de fevereiro de 2021). LAQUEUR, Thomas. 2001. Inventando o Sexo: corpo e gênero dos gregos a Freud. Rio de Janeiro: Relume Dumará.

LUNA, Naara.2007. “A personalização do embrião humano: da transcendência na biologia”. Revista Mana, n.13(2): 411-440. 


\section{Nanduty}

ISSN:2317-8590

RODOVALHO, Amara Moira. 2017, “O cis pelo trans". In: Revista de Estudos Feministas, Florianópolis, 25(1): 422.

SOUZA, Erica. 2014. "Papai é homem ou mulher? Questões sobre a parentalidade transgênero no Canadá e a homoparentalidade no Brasil". Revista de Antropologia, São Paulo, v. 56, n. 2: 397-430. In: https://www.revistas.usp.br/ra/article/view/82527 (acessado em 02 de fevereiro de 2021).

SCHNEIDER, David.1980. American Kinship: a cultural account. New Jersey: Prentice-Hall. STRATHERN, Marilyn. 1992. Reproducing the future: essays on anthropology, kinship and the new reproductive Technologies. Manchester: Manchester University Press.

TAMANINI, Marlene. 2009. Reprodução assistida e gênero: o olhar das ciências humanas. Florianópolis: Ed. UFSC.

THOMPSON, Charis. 2005. Making parents: the ontological choreography of reproductive technologies. Cambridge: The Mit Press.

ZAMBRANO, Elisabeth. 2006. "Parentalidades "impensáveis": pais/mães homossexuais, travestis e transexuais". Horizontes Antropológicos, Porto Alegre, ano 12, n. 26, jul./dez. 